\title{
PENGARUH KETERLIBATAN ORANG TUA DALAM BELAJAR TERHADAP PRESTASI BELAJAR SISWA SEKOLAH DASAR NEGERI PINTUKISI
}

\author{
Ayu Safitri', Din Azwar Uswatun ${ }^{2}$, Dyah Lyesmaya ${ }^{3}$ \\ 1,2,3PGSD FKIP Universitas Muhammadiyah Sukabumi \\ 1 ayusafiti06@gmail.com , 2 dinazwar@ummi.ac.id , \\ 3 Iyesmaya_dyah@ummi.ac.id,
}

\begin{abstract}
The purpose of this study is to describe the influence of parental involvement on learning achievement in the Pintukisi Public Elementary School in Sukabumi City. This research was conducted at the Pintukisi Public Elementary School in Sukabumi City. The method used in this research is quantitative method. The type of research used is ex post facto. Data collection techniques that researchers use in this study are observation, interviews, questionnaires, and documentation. The sampling technique used is the probability sampling type of random sampling and in this case there are 30 students and 30 parents. In this study, data analysis used is correlation statistical analysis, analysis prerequisite test, and final analysis or hypothesis testing. The results showed that there was an influence of parental involvement on learning achievement in Pintukisi Public Elementary School, Sukabumi City
\end{abstract}

Keywords: Parental Involvement, Learning Achievement, Learning

\begin{abstract}
ABSTRAK
Tujuan penelitian ini yaitu untuk mendeskripsikan pengaruh keterlibatan orangtua terhadap prestasi belajar di Sekolah Dasar Negeri Pintukisi Kota Sukabumi. Penelitian ini dilaksanakan pada Sekolah Dasar Negeri Pintukisi Kota Sukabumi. Metode yang digunakan dalam penelitian ini adalah metode kuantitatif. Jenis penelitian yang digunakan yaitu ex post facto. Teknik pengumpulan data yang peneliti gunakan dalam penelitian ini yaitu observasi, wawancara, angket, dan dokumentasi. Teknik pengambilan sampling yang digunakan adalah teknik probability sampe/ bertipe random sampling dan dalam hal ini yaitu adalah 30 Siswa dan 30 orangtua. Pada penelitian ini, analisis data yang digunakan yaitu analisis statistik korelasi, uji prasyarat analisis, dan analisis akhir atau pengujian hipotesis. Hasil penelitian menunjukan bahwa terdapat pengaruh keterlibatan orangtua terhadap prestasi belajar di Sekolah Dasar Negeri Pintukisi Kota Sukabumi
\end{abstract}

Kata Kunci: Keterlibatan Orangtua , Prestasi Belajar, Pembelajaran 


\section{A. Pendahuluan}

Sekolah identik dengan pendidikan, berkaitan dengan itu pendidikan dapat diartikan sebagai pengajaran yang diselenggarakan oleh sekolah sebagai lembaga tempat mengajar dan belajar. Belajar merupakan suatu poses untuk mengetahui ilmu pengetahuan, meningkatkan keterampilan dan rasa percaya diri pada siswa, namun tentu saja harus ada peningkatan kualitas dan kuantitas. Pendidikan merupakan usaha sadar yang dilakukan secara terencana untuk mendidik dan membekali peserta didik dengan nilai, pengetahuan dan keterampilan agar peserta didik memiliki karakter positif, kemampuan serta keterampilan yang berguna untuk kehidupannya.

Tujuan pendidikan nasional dapat diwujudkan melalui pendidikan yang bermutu. Pendidikan bermutu adalah pendidikan yang mampu menghasilkan lulusan berakhlak mulia, memiliki kecakapan hidup serta memiliki kompetensi baik akademik ataupun non akademik yang dapat bersaing seiring dengan perkembangan zaman. Peningkatan mutu pendidikan terus dilakukan melalui berbagai cara, mengingat pendidikan merupakan kebutuhan manusia yang harus dipenuhi sepanjang hayat. Agar peningkatan mutu pendidikan dapat terus berjalan dengan baik, diperlukan tenaga pendidik yang professional. Melalui tenaga pendidik yang professional, diharapkan proses pembelajaran akan berjalan dengan lancar.

Pembelajaran adalah pemberdayaan potensi peserta didik menjadi kompetensi. Kegiatan pemberdayaan ini tidak dapat berhasil tanpa ada orang yang membantu. Salah satu pertanda bahwa seseorang telah belajar sesuatu adalah adanya perubahan tingkah laku dalam dirinya. Perubahan tingkah laku tersebut menyangkut baik perubahan yang bersifat pengetahuan (kognitif), keterampilan (psikomotor) maupun yang menyangkut nilai dan sikap (afektif).

Belajar tidak hanya meliputi mata pelajaran, tetapi juga penguasaan, kebiasaan, persepsi, kesenangan, kompetensi, penyesuaian sosial, bermacammacam keterampilan, dan cita-cita. Penelitian tersebut menjelaskan, bahwa belajar tidak selalu di sekolah tetapi belajar dengan lingkungan disekitar seperti masyarakat juga di rumah merupakan bagian dari proses 
belajar, kemudian ini akan memberikan hasil yaitu prestasi belajar.

Prestasi belajar merupakan gabungan dari dua kata, yaitu prestasi dan belajar, dimana setiap kata nya mempunyai arti dan makna yang berbeda. Prestasi merupakan suatu hasil yang telah dicapai dari aktivitas yang sudah dikerjakan. Belajar ialah suatu proses yang dilakukan seseorang untuk memperoleh suatu perubahan tingkah laku yang baru secara keseluruhan sebagai hasil pengalamannya sendiri dalam berinteraksi dengan lingkungannya (Slameto, 2015: 2). Maka prestasi belajar dapat diartikan sebagai sebuah pencapaian hasil belajar baik individu/kelompok dari kegiatan yang menghasilkan adanya perubahan dalam tingkah laku yang dialami oleh individu/kelompok (subyek belajar) dalam suatu interaksi dan dalam lingkungannya. Kemudian dengan mengetahui prestasi belajar siswa akan diketahui kedudukan anak dalam kelas, apakah anak termasuk kedalam anak yang kurang, sedang, atau pandai.

Prestasi belajar dipengaruhi oleh dua faktor untuk dapat membantu siswa dalam rangka pencapaian prestasi belajar yaitu faktor internal dan faktor eksternal. (Slameto, 2015: 54). Salah satu faktor eksternal yaitu Faktor Keluarga. Peran orang tua sebagai keluarga sangat penting dalam hal pendidikan, hal tersebut berarti orang tua anak wajib ikut terlibat dalam hal proses pendidikan. Keluarga memiliki peranan yang penting dalam pendidikan anak. Dalam hal ini, orangtua sebagai guru pertama bagi anak.

Orang tua merupakan individu yang terdekat dengan anak, yang sangat mengerti dan memahami anak serta bertanggung jawab terhadap anak. Orang tua juga membentuk sikap kepada anak dengan memberikan tekanan, tekanan itu dapat dilakukan baik secara langsung maupun tidak langsung agar dapat mencapai tujuan yang diharapkan oleh orang tua. Upaya lain orang tua adalah memberikan anak perhatian yang tinggi untuk mengupayakan anaknya berprestasi dengan menyediakan segala kebutuhan belajar, sehingga anak akan terpanggil untuk belajar dengan giat yang dirasakan sebagai panggilan hati nurani atau komitmen.

Peran orang tua adalah sesuatu yang diharapkan oleh anak dari ayah 
dan ibunya. Peranan orang tua dalam upaya meningkatkan prestasi belajar anak sangat baik jika orang tua ikut terlibat dalam proses pembelajarannya. Untuk senantiasa meningkatkan hasil prestasi belajar siswa, orang tua dapat ikut serta berperan dengan memberikan waktu yang cukup untuk belajar pada anak, pemberian motivasi dalam belajar, kebutuhan anak terpenuhi, dan selalu terlibat dalam belajar anak-anaknya dalam upaya meningkatkan prestasi atau hasil belajar.

Anak begitu sangat membutuhkan keterlibatan orang tua dalam belajar, khususnya pada anak di usia sekolah dasar. Di sekolah anak banyak mendapatkan pembelajaran yang diberikan oleh guru, proses pembelajaran yang baik maka anakanak akan berperan dan terlibat secara aktif. Peningkatan kemampuan mental pada anak-anak itu akan terjadi dan anak-anak akan mengalami proses tersebut. Dengan belajar kemudian anak akan mendapatkan Hasil atau evaluasi belajar.

Belajar anak yang di dapatkan disekolah merupakan suatu hasil interaksi tindak belajar dan tindak mengajar. Tindak mengajar guru diakhiri oleh evaluasi hasil belajar yang diperoleh siswa sedangkan tindak belajar pada saat evaluasi hasil belajar itu adalah puncaknya dari sebuah proses pembelajaran. Hasil belajar kemudian dapat dibedakan menjadi dua dampak yaitu dampak pengiring dan dampak pengajaran. Dampak pengajaran merupakan hasil yang dapat diukur, seperti hasil rapor, tes, dan lainnya yang tertuang dalam bentuk angka. Kemudian Penelitian ini dilakukan di SDN Pintukisi Kota Sukabumi. Pemilihan SDN Pintukisi Kota Sukabumi sebagai subjek penelitian didasarkan pada keberagaman anak dengan orang tuanya sehingga jika dilihat dalam beberapa faktor, terdapat banyak sekali faktor contohnya seperti sarana dan prasarana, lingkungan rumah dan sekolah, pemberian perhatian, dll.

Berdasarkan hasil proses wawancara yang dilakukan bersama guru dan kepala sekolah SDN Pintukisi Kota Sukabumi. Keterlibatan orang tua dalam proses belajar di kelas IV-VI SDN Pintukisi cukup rendah, keterlibatan orang tua dapat dilihat dalam beberapa hal, salah satunya ketersediaan waktu dari orang tua mendampingi anaknya dalam belajar. Namun, kesibukan 
orang tua terkadang menjadi hambatan untuk terlibatnya orang tua dalam proses belajar anak, salah satu contohnya yaitu orang tua dari siswasiswi SDN Pintukisi Kota Sukabumi. Sekitar $60 \%$ ibu-ibu yang menyekolahkan anaknya di SDN Pintukisi Kota Sukabumi adalah ibuibu wanita karir. Sedangkan, ayah dari siswa-siswi di sekolah tersebut $99 \%$ memiliki pekerjaan. Di SDN Pintukisi Kota Sukabumi juga belum pernah dilakukan penelitian mengenai keterlibata orang tua pada proses belajar anaknya. Oleh karena itu, peneliti tertarik melakukan penelitian di Pintukisi Kota Sukabumi. Berdasarkan data penelitian diatas, begitu sangat pentingnya keterlibatan orangtua, maka peneliti akan mengkaji tentang permasalahan tersebut dengan melakukan penelitian dengan judul "Pengaruh keterlibatan orangtua dalam belajar terhadap prestasi belajar di Sekolah Dasar Negeri Pintukisi Kota Sukabumi."

\section{B. Metode Penelitian}

Penelitian ini dilaksanakan pada Sekolah Dasar Negeri Pintukisi Kota Sukabumi. Metode yang digunakan dalam penelitian ini adalah metode kuantitatif. Jenis penelitian yang digunakan yaitu ex post facto. Teknik pengumpulan data yang peneliti gunakan dalam penelitian ini yaitu observasi, wawancara, angket, dan dokumentasi. Teknik pengambilan sampling yang digunakan adalah teknik probability sampel bertipe random sampling dan dalam hal ini yaitu adalah 30 Siswa dan 30 orangtua. Pada penelitian ini, analisis data yang digunakan yaitu analisis statistik korelasi, uji prasyarat analisis, dan analisis akhir atau pengujian hipotesis.

\section{C.Hasil Penelitian dan Pembahasan}

Dalam penelitian ini terdiri dari satu variable bebas yaitu Keterlibatan Orang Tua (X1) dan Keterlibatan Anak (X2) serta variable terikat yaitu Prestasi Belajar Siswa (Y). Untuk mendeskripsikan dan menguji hubungan variabel bebas dan variabel terikat dalam penelitian ini maka pada bab ini akan disajikan data yang diperoleh dilapangan

Data keterlibatan orangtua diperoleh melalui data primer dengan teknik pengumpulan data menggunakan menggunakan kuesioner (angket) kepada 30 orang tua di SDN Pintukisi 
Dari nilai yang dihasilkan oleh skor jawaban keterlibatan orangtua yang dibagikan kepada sebanyak 30 orangtua, didapatkan rata-rata keterlibatan orangtua yaitu 88,73 ; nilai minimum 46,00; nilai maksimum 112,00; median, 90,50; modus; 95,00 dan standar deviation 13,393. Daftar distribusi frekuensi skor jawaban orangtua tersebut kemudian disajikan dalam bentuk histogram yang dapat dilihat seperti pada Gambar 1 di bawah ini:

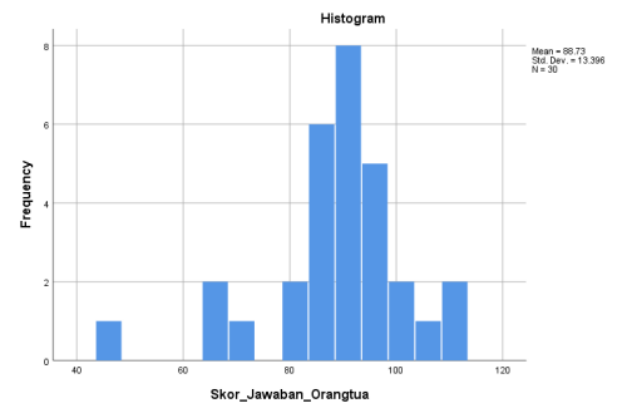

Gambar 1. Histogram Distribusi Frekuensi Skor Jawaban Orangtua

Dari nilai yang dihasilkan oleh skor jawaban keterlibatan orangtua yang dibagikan kepada sebanyak 30 siswa, didapatkan rata-rata keterlibatan orangtua yaitu 86,2 ; nilai minimum 43,00; nilai maksimum 114,00; median, 85,50; modus; 85,00 dan standar deviation 15,045. Daftar distribusi frekuensi skor jawaban anak tersebut kemudian disajikan dalam bentuk histogram yang dapat dilihat seperti pada Gambar 2 di bawah ini:

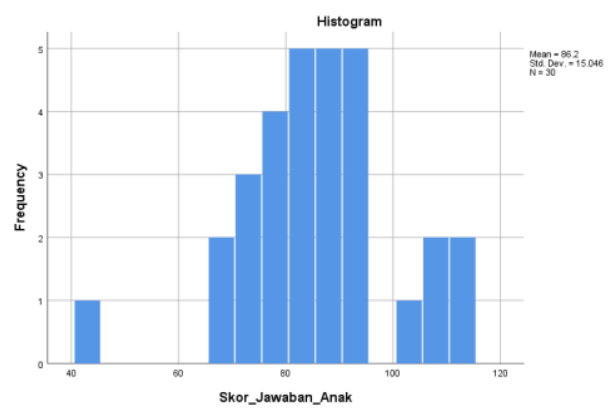

Gambar 2. Histogram Distribusi Frekuensi Skor Jawaban Anak Data prestasi belajar diperoleh melalui data sekunder dengan teknik pengumpulan data menggunakan menggunakan dokumentasi pada nilai raport 30 orang tua di SDN Pintukisi.

Dari nilai yang dihasilkan oleh prestasi belajar yang didapat dari 30 siswa, didapatkan rata-rata prestasi belajar yaitu 85,3 ; nilai minimum 74,00; nilai maksimum 95,00; median, 85,50; modus; 84,50 dan standar deviation 4,822. Daftar distribusi frekuensi prestasi belajar tersebut kemudian disajikan dalam bentuk histogram yang dapat dilihat seperti pada Gambar 3 di bawah ini:

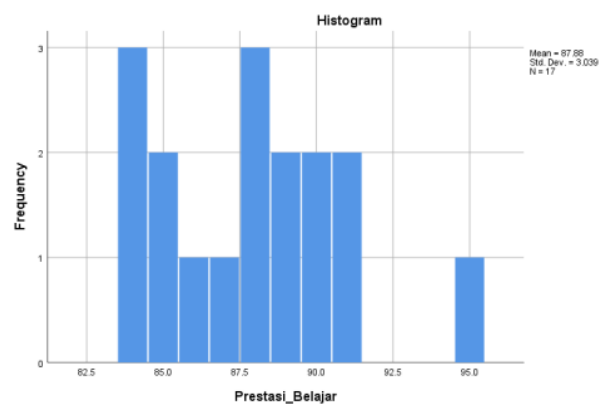

Gambar 3. Histogram Distribusi Frekuensi Skor Prestasi Belajar 
Tabel 1

Kriteria Penilaian Prestasi Belajar

\begin{tabular}{|c|c|l|}
\hline $\begin{array}{c}\text { Angka } \\
100\end{array}$ & $\begin{array}{c}\text { Angka } \\
10\end{array}$ & Kriteria \\
\hline $80-100$ & $8,0-10,0$ & $\begin{array}{l}\text { Baik } \\
\text { sekali }\end{array}$ \\
\hline $66-79$ & $6,6-7,9$ & Baik \\
\hline $56-65$ & $5,6-6,5$ & Cukup \\
\hline $40-55$ & $4,0-5,5$ & Kurang \\
\hline $30-39$ & $3,0-3,9$ & Gagal \\
\hline
\end{tabular}

Sumber: Arikunto (2013:281)

Berdasarkan kriteria penilaian prestasi belajar pada tabel 4.3 dengan jumlah rata-rata prestasi belajar 85,3 maka masuk dalam kategori baik sekali, dapat diartikan bahwa prestasi belajar di SDN Pintukisi Kota Sukabumi sudah sangat baik.

Hasil penelitian menunjukan bahwa terdapat hubungan yang positif antara keterlibatan orang tua terhadap prestasi belajar pada siswa SDN Pintukisi Kota Sukabumi dibuktikan dengan nilai $\mathrm{T}_{\text {hitung }}$ lebih besar daripada $T_{\text {tabel }}$ dimana nilai $T_{\text {hitung }}$ $5,381>\mathrm{T}_{\text {tabel }} 1,70113$ maka $\mathrm{H}_{0}$ ditolak dan $\mathrm{H}_{1}$ diterima.. Hal ini menguatkan kembali pada hasil penelitian yang relevan yang dilakukan oleh (Tolada, 2012; Zulifah, 2011; Hardiana, Salman, Amirulloh, dan Ryzza, 2011) yang menyatakan bahwa terdapat hubungan yang positif dan signifikansi antara keterlibatan orang tua terhadap prestasi belajar siswa.

Besarnya pengaruh keterlibatan orang tua dalam belajar terhadap prestasi belajar siswa tergolong tinggi dengan koefisien $R$ sebesar 0,731. Kontribusi variabel $X$ terhadap $Y$ sebesar 0,508 atau $50,8 \%$ kemudian sisanya $49,2 \%$ ditentukan oleh faktor lain. Keterlibatan orangtua pada siswa SDN Pintukisi Kota Sukabumi dinilai sudah cukup baik. Hal ini terbukti pada hasil akhir raport dengan rata rata pada kategori baik sekali, dan keterlibatan orangtua pun secara umum dapat dikatakan berperan penting dalam diri seorang siswa. Hal ini menguatkan pernyataan dari Shochib (2010: 18) yang menyatakan bahwa keterlibatan orang tua merupakan esensi keluarga (ibu dan ayah) menjadi kesatuarahan dan kesatutujuan atau keutuhan dalam mengupayakan anak untuk memiliki dan mengembangkan dasar-dasar disiplin diri. Selain itu upaya orang tua adalah mengatur tempat belajar, penciptaan suasana yang tentram, sehingga anak terdorong untuk belajar. Upaya lain orang tua adalah memberikan anak perhatian yang tinggi untuk mengupayakan anaknya berprestasi dengan menyediakan 
segala kebutuhan belajar, sehingga anak akan terpanggil untuk belajar dengan giat yang dirasakan sebagai panggilan hati nurani atau komitmen.

Dari hasil penelitian dapat ditarik kesimpulan bahwa peran orangtua sangat penting dalam meningkatkan prestasi belajar. Peran orang tua adalah sesuatu yang diharapkan oleh anak dari ayah dan ibunya. Adapun menurut Shochib (2010: 29) orang tua dalam keluarga berperan sebagai guru, penuntun, pengajar, serta sebagai pemimpin pekerjaan dan pemberi contoh. Peranan orang tua dalam upaya meningkatkan prestasi belajar anak sangat baik jika orang tua ikut terlibat dalam proses pembelajarannya. Untuk senantiasa meningkatkan hasil prestasi belajar siswa, orang tua dapat ikut serta berperan dengan memberikan waktu yang cukup untuk belajar pada anak, pemberian motivasi dalam belajar, kebutuhan anak terpenuhi, dan selalu terlibat dalam belajar anak-anaknya dalam upaya meningkatkan prestasi atau hasil belajar.

\section{E. Kesimpulan}

Berdasarkan analisis data, pengujian hipotesis serta hasil dan pembahasan yang telah dikemukakan peneliti dapat diambil simpulan sebagai berikut. Skor rata-rata keterlibatan orang tua dalam belajar di SDN Pintukisi yaitu 88,85 dan untuk skor jawaban anak yaitu 86,2. Nilai rata-rata prestasi belajar siswa SDN Pintukisi yaitu 85,3 maka masuk dalam kategori baik sekali, dapat diartikan bahwa prestasi belajar di SDN Pintukisi Kota Sukabumi sudah sangat baik. Nilai terkecil rata-rata prestasi belajar siswa SDN Pintukisi yaitu 74,00 dan nilai terbesar rata-rata prestasi belajar siswa SDN Pintukisi yaitu 95,00. Terdapat pengaruh yang signifikan antara keterlibatan orang tua dalam belajar terhadap prestasi belajar siswa SDN Pintukisi.

Berdasarkan hasil penelitian yang telah dilakukan, maka peneliti memberikan saran sebagai berikut.

1. Pihak sekolah hendaknya mengadakan pertemuan rutin antara orang tua dan sekolah untuk meningkatkan keterlibatan orang tua dalam belajar terhadap prestasi belajar siswa, sehingga siswa dapat mencapai prestasi yang memuaskan.

2. Pihak guru, karena sekolah merupakan lembaga pendidikan setelah keluarga hendaklah memperhatikan perkembangan 
siswa terutama yang mempunyai prestasi rendah atau mempunyai kesulitan dalam belajar.

3. Pihak orang tua, sebaiknya selalu terlibat dalam belajar anak dan kegiatan anak sehingga anak menjadi lebih terpantau dalam prestasi belajarnya. Keluarga memberikan dasar pembentukan tungkah laku, watak, moral dan pendidikan pada siswa. Pengalaman interaksi di dalam keluarga akan menentukan pula tingkah laku siswa terhadap orang lain dalam masyarakat.

4. Pihak luar, penelitian ini diharapkan dapat dijadikan sebagai sarana informasi sehingga dalam penelitian selanjutnya dapat memperbaiki keterbatasan yang ada dalam penelitian ini dengan melakukan penelitian pada lokus penelitian yang berbeda dan memperluas variabel mengenai keterlibatan orangtua dan prestasi belajar agar dapat mengembangkan penelitian dengan menggunakan variabel lain, sehingga dapat mendukung dalam penelitian selanjutnya.

\section{DAFTAR PUSTAKA}

Arikunto, Suharsimi. 2006. Prosedur Penelitian. Jakarta: Rineka Cipta

Arikunto, Suharsimi. 2013. Prosedur Penelitian Suatu Pendekata Praktik. Jakarta: Rineka Cipta

Diadha, R. (2015). Keterlibatan Orang Tua Dalam Pendidikan Anak Usia Dini Di Taman Kanak-Kanak. Edusentris, 2(1), 61.

Faturohman, M., \& Sulistyorini. (2018a). Belajar dan pembelajaran. kalimedia.

Faturohman, M., \& Sulistyorini. (2018b). Belajar dan Pembelajaran. Depok Sleman Yogyakarta: Kalimedia.

hamid darmadi. (2014). metode penelitian pendidikan dan sosial (1st ed.). alfabeta, cv.

Junianto, D., \& Yogyakarta, U. N. (2013). "Pengaruh kinerja mengajar guru , keterlibatan orang tua, aktualisasi diri dan motivasi berprestasi the influence of teachers, teaching performance, parents involvement, self -actualization, and". Jurnal Pendidikan Vokasi, 3, 307-319.

Koskei K. 2014 "Influence Of Parental Involvemen On Student's Academic Performance Of Public Mixed Day Secondary Schools In Kuresoi Sub-Century ,Nakuru, Kenya " Jurnal Education and reaserch vol 2 issues 12 .

Notoatmodjo, S. (2010). Metodologi penelitian kesehatan. jakarta: Rineka cipta.

Ridwan. (2009). ketercapaian prestasi belajar. Retrieved March 25, 


\section{9, from}

Schunk, H., D., Meece, J. R., \& Paul, P. (2012). Motivation in education: Theory, research, and applications. Pearson Higher Ed.

Shochib, M. (2018). Pola asuh orang tua ( dalam membantu mengembangkan disiplin diri sebagai pribadi yang berkarakter) (2nd ed.). jakarta: PT Rineka cipta.

Slameto. (2015). Belajar dan faktorfaktor yang mempengaruhinya (6th ed.). jakarta: PT Rineka cipta.

Sugiono. (2014a). Metode Penelitian Kombinasi (Mixed Methods). bandung alfabeta.

Sugiono. (2014b). Metode Penelitian Kombinasi (Mixed Methods). bandung alfabeta.

Sukmadinata, nana syaodih. (2016). metode penelitian pendidikan (11th ed.). pt remaja rosdakarya.

Suyono, \& Hariyanto. (2016). belajar dan pembelajaran (6th ed.; anang solihin Wardan, Ed.). Bandung.

Tolada, T. (2012). Hubungan keterlibatan orang tua dengan prestasi belajar anak usia sekolah di SD IT permata hati, banjar negara. 